Historic, Archive Document

Do not assume content reflects current scientific knowledge, policies, or practices. 


\section{ABSTRACT}

Volumes are in total cubic feet and cubic feet to a 4.0-inch top, board feet Scribner Rule to 6-inch and 8-inch tops, and board feet International $1 / 4$-inch Rule to 6 -inch and 8-inch tops. Tree heights are in feet and numbers of logs. Volume equations are of the form $\mathrm{V}=\mathrm{a}+\mathrm{bD}^{2} \mathrm{H}$.

Keywords: Tree volume tables, tree volume estimates, stand volume estimates, Picea engelmannii. 


\title{
Volume Tables and Point-Sampling Factors for Engelmann Spruce in Colorado and Wyoming
}

\author{
by \\ Clifford A. Myers, Principal Mensurationist, \\ and \\ Carleton B. Edminster, Research Forester \\ Rocky Mountain Forest and Range Experiment Station '
}

\footnotetext{
'Central headquarters maintained in cooperation with Colorado State University at Fort Collins.
} 
Definitions and Standards ...................

Explanation of Tables ..................... 2

Volume Tables ........................ 2

Point-Sampling Factors ................. 2

Literature Cited ......................... 3

List of Tables

1. Gross volumes of entire stem in cubic feet . . . . . . . . . 5

2. Gross merchantable volumes in cubic feet to a

4.0-inch top, total height ............ 6

3. Gross merchantable volumes in cubic feet per

square foot of basal area ............ 7

4. Gross volumes in board feet Scribner Rule,

6 -inch top, total height ............. 8

5, Gross volumes in board feet Scribner Rule,

per square foot of basal area, total height . . . . . . 9

6. Gross volumes in board feet Scribner Rule,

6 -inch top, height in logs ............ 10

7. Gross volumes in board feet Scribner Rule

per square foot of basal area, height in logs . . . . . 11

8. Gross volumes in board feet Scribner Rule,

8-inch top, total height .............. 12

9. Gross volumes in board feet Scribner Rule

per square foot of basal area, total height ....... 13

10. Gross volumes in board feet Scribner Rule,

8 -inch top, height in logs ............. 14

11. Gross volumes in board feet Scribner Rule

per square foot of basal area, height in logs . . . . . 15

12. Gross volumes in board feet International $1 / 4$-inch

Rule, 6-inch top, total height ............ 16

13. Gross volumes in board feet International $1 / 4$-inch Rule

per square foot of basal area, total height . . . . . 17

14. Gross volumes in board feet International $1 / 4$-inch

Rule, 6 -inch top, height in logs .......... 18

15. Gross volumes in board feet International $1 / 4$-inch Rule

per square foot of basal area, height in logs . . . . . 19

16. Gross volumes in board feet International $1 / 4$-inch

Rule, 8-inch top, total height ............ 20

17. Gross volumes in board feet International $1 / 4$-inch Rule

per square foot of basal area, total height ....... 21

18. Gross volumes in board feet International $1 / 4$-inch

Rule, 8-inch top, height in logs ........... 22

19. Gross volumes in board feet International $1 / 4$-inch

Rule, height in logs . . . . . . . . . . . 


\title{
Volume Tables and Point-Sampling Factors for Engelmann Spruce
}

\section{in Colorado and Wyoming}

\author{
Clifford A. Myers and Carleton B. Edminster
}

Nineteen tables presented here give values needed to determine the volumes of Engelmann spruce (Picea engelmannii Parry) trees in Colorado and southern Wyoming. They provide the following:

1. Gross volumes in total and merchantable cubic feet.

2. Gross volumes in board feet, Scribner and International $1 / 4$-inch log rules.

3. Point-sampling factors for merchantable cubic feet and board feet.

Volume on an area may be determined from: (1) measurements of tree diameters and heights, (2) measurements of diameters and of sufficient heights to convert the appropriate volume tables to local volume tables (Chapman and Meyer 1949), or (3) tree counts obtained by point-sampling.

Sample trees were measured by personnel of the Colorado State Forest Service and of the USDA Forest Service on the following eight National Forests: Arapaho, Grand Mesa-Uncompahgre, Gunnison, Medicine Bow, Rio Grande, Routt, San Juan, and White River.

\section{Definitions and Standards}

Variables used in the tables, and standards followed in field measurement and computations, are as follows:

Diameter breast high (d.b.h.). - Measured to 0.1 inch outside bark 4.5 feet above ground level at the uphill side of the tree. Full-inch diameter classes, with class midpoints at the half-inch marks, were used in the tables (12.5, 13.5, and so forth).
Scaling diameter of logs. - Average diameter inside bark to 0.1 inch, measured at the upper (small) end of logs or half-logs. Sawlog diameter classes followed conventional scaling practice, with class midpoints at whole inches $(12.0,13.0$, and so forth).

Minimum top diameters for board-foot volumes. - Two minimum top diameters inside bark, 6 and 8 inches. Actual utilization practices indicate that both limits are used for Engelmann spruce, and that the limit does not vary with tree diameter. Logs with a scaling diameter less than 5.6 inches for the 6-inch top and 7.6 inches for the 8-inch top usually were not included in saw-log volume. A few logs with smaller scaling diameters were included to satisfy requirements of the 4-foot rule, described below. This also conforms to local practice.

Total height. - Measured to the nearest foot from ground level at the tree base upward to the tip. Forked, stag-topped, or other deformed trees were not included in the sample. Midpoints of the total height classes used in the tables were multiples of 10.0 feet.

Height in logs. - Measured from the top of a stump 1.0 foot high upward to the limit of saw-log utilization. Each tree was divided into as many 16.5-foot-long logs as possible. An additional half-log, if present, was taken from the uppermost part of the merchantable length. Portions of the bole above the height of minimum top saw-log diameter were included in the uppermost saw-log if the standard length of the log or half-log ended within 4.0 feet above this height. This "4-foot rule" was used to avoid biased negative error in volume (Chapman and Meyer 1949). 


\section{Explanation of Tables}

General definitions and standards given above apply to all tables. Explanation of each type of table and suggestions for use are presented here.

\section{Volume Tables}

Headings and footnotes with each volume table (table 1 and even-numbered tables) give the volume unit, type of height measurement, utilization standards, and volume equations used in its compilation. Ten-foot or half-log height classes and full-inch diameter classes were used in all tables.

The volume tables were derived from linear regressions in $\mathrm{V}$ and $\mathrm{D}^{2} \mathrm{H}$, of the form:

$\mathrm{V}=\mathrm{a}+\mathrm{b} \mathrm{D}^{2} \mathrm{H}$

where:

$\mathrm{V}=$ gross volume in the appropriate unit,

$\mathrm{D}=$ diameter breast high outside bark,

$\mathrm{H}=$ total height in feet or in standard logs and half-logs, and

$\mathrm{a}, \mathrm{b}=$ regression constants

Two equations were used to derive each table except for table 8. Usually, the relationship between $\mathrm{V}$ and $\mathrm{D}^{2} \mathrm{H}$ could not be expressed by a single linear regression over the full range of the basic data.

The number of logs in a tree shown in the tables is not necessarily the number that will actually be cut from it. Instead, it is the number of logs between the 1.0-foot stump and the height where minimum top diameter is reached. Volume of nonmerchantable logs below the height of minimum top diameter should be deducted from tree volume by: (1) estimation of scaling diameters and deduction of appropriate log volumes, (2) use of taper tables to determine scaling diameters and deduction of log volumes, or (3) reduction of total volume by the percentage of volume contained in the nonmerchantable log. Volume must not be reduced by tallying fewer logs in the tree.

\section{Point-Sampling Factors}

Tables of point-sampling factors (oddnumbered tables from 3 to 19 , inclusive) give the factors for each of numerous combinations of tree diameter and height. Tabulated volumes per square foot of basal area were obtained from the equations in the table footnotes. These equations resulted from the division of each term of the corresponding tree volume equation by $0.005454 \mathrm{D}^{2}$, a formula for basal area (B).
Point-sample cruising for volume can be done in several ways: (1) measure the diameter and height of each tree counted through the prism or relascope, (2) measure the height of each counted tree and estimate its diameter, pr (3) measure the heights of the counted trees and make no record of the diameters. The procedure selected will depend on the accuracy desired (relative accuracy usually in the order listed above) and the time and personnel available for the job.

If the diameter and height of each counted tree are measured, a volume conversion factor is selected for each combination of diameter and height. Factors are read from the appropriate factor table (odd-numbered tables from 3 to 19 , inclusive) or computed from equations in the table footnotes. Volume per acre is computed as follows:

1. Multiply the number of counted trees in each diameter-height class by the point-sampling factor for the class.

2. Total the products of step one.

3. Multiply this total by the basal area factor of the prism or other angle gage used.

4. Divide the product of step three by the number of points sampled on the tract.

Time can often be saved if the heights of the counted trees are measured, while diameters are estimated and tallied by broad diameter classes. Inspection of the factor tables shows that volumes per square foot of basal area often do not differ greatiy among trees of a single height class. For example, the merchantable cubic volumes of trees 70 feet tall vary from 26.2 to 29.4 cubic feet per square foot as diameter increases from 5 to 23 inches (table 3 ). Board feet per square foot of basal area changes little with diameter when tree heights are measured in logs (tables $7,11,15,19$ ). Therefore, the increased time spent measuring diameters may not increase accuracy materially.

It is recommended that diameters not be recorded at all when the distribution of diameters and heights on the area inventoried indicates there is little change in volume per square foot within a height class. Point-sampling factors based on height only can be computed from the factor tables given here.

The factor for each height class can be computed using almost the same procedure used to derive a local volume table from a standard table (Chapman and Meyer 1949). Diameters are plotted over heights, since height will be retained as the measured variable.

The techniques of point sampling have been adequately described in numerous publications (Bonnett 1959, Grosenbaugh 1952, 1955, 1958). 


\section{Literature Cited}

Bonnett, Howbert W.

1959. Guide for variable plot cruising. L'.S.

Dep. Agric., Forest Serv., Region 4, Ogden, Utah. 38 p.

Chapman, Herman H., and Walter H. Meyer.

1949. Forest mensuration. 522 p. N. Y.: McGraw-Hill Book Co., Inc.

Grosenbaugh, L. R.

1952. Plotless timber estimates - new, fast, easy. J. For. 50: 32-37.
1955. Better diagnosis and prescription in southern forest management. U.S. Dep. Agric., Forest Serv. South. Forest Exp. Stn., Occas. Pap. 145, 27 p.

1958. Point-sampling and line-sampling: Probability theory, geometric implications, synthesis. U. S. Dep. Agric., Forest Serv., South. Forest Exp. Stn., Occas. Pap. 160, 34 p. 



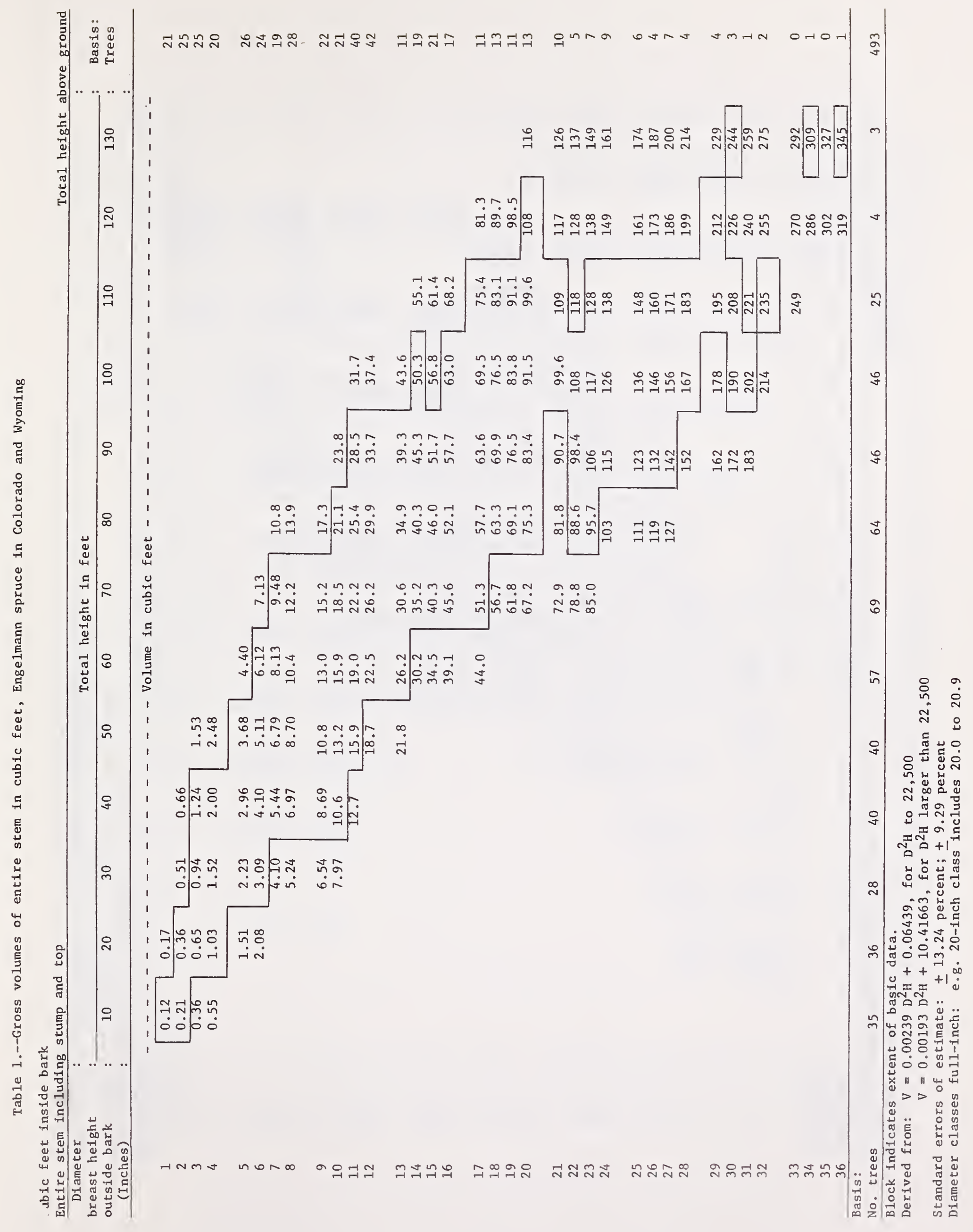




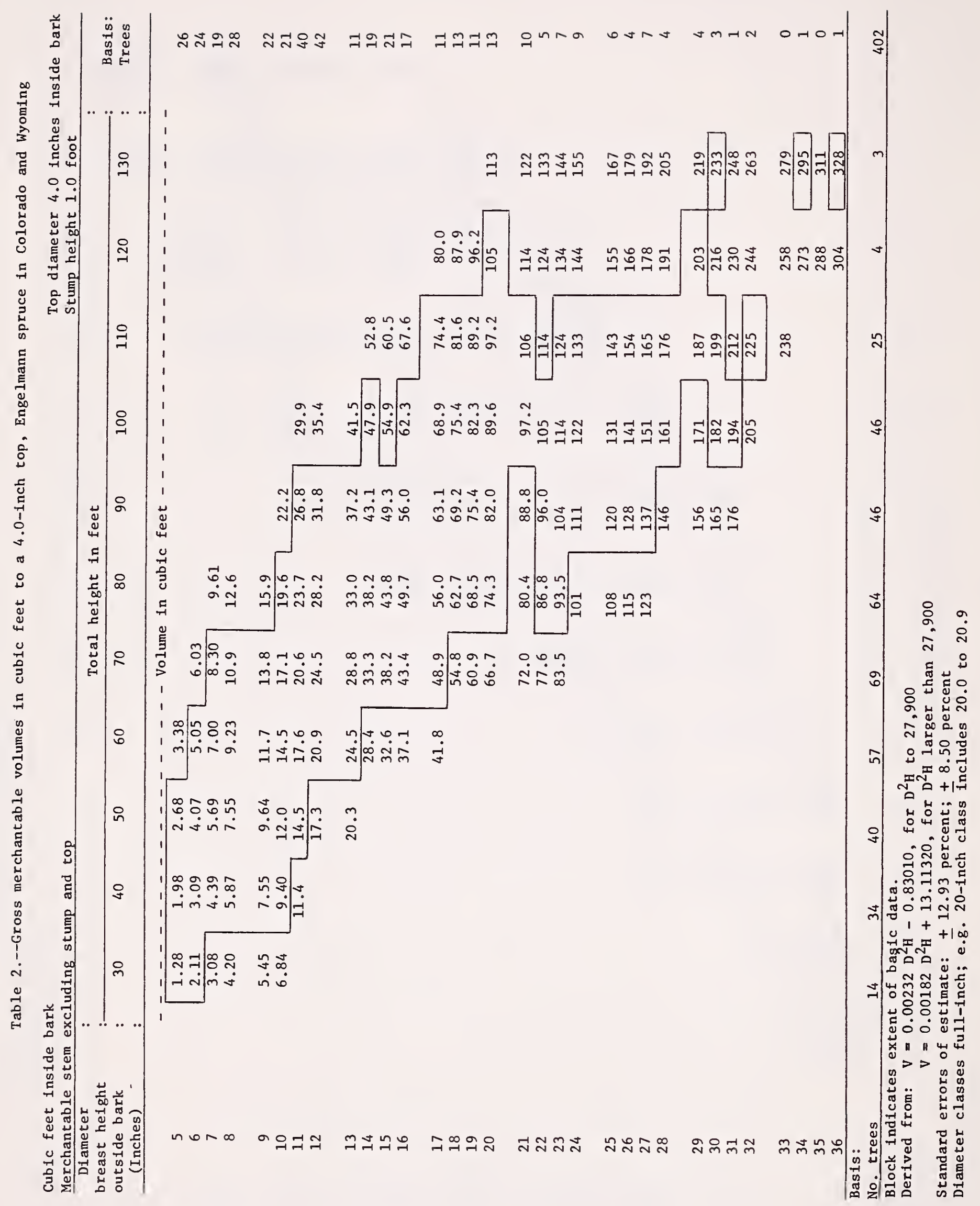




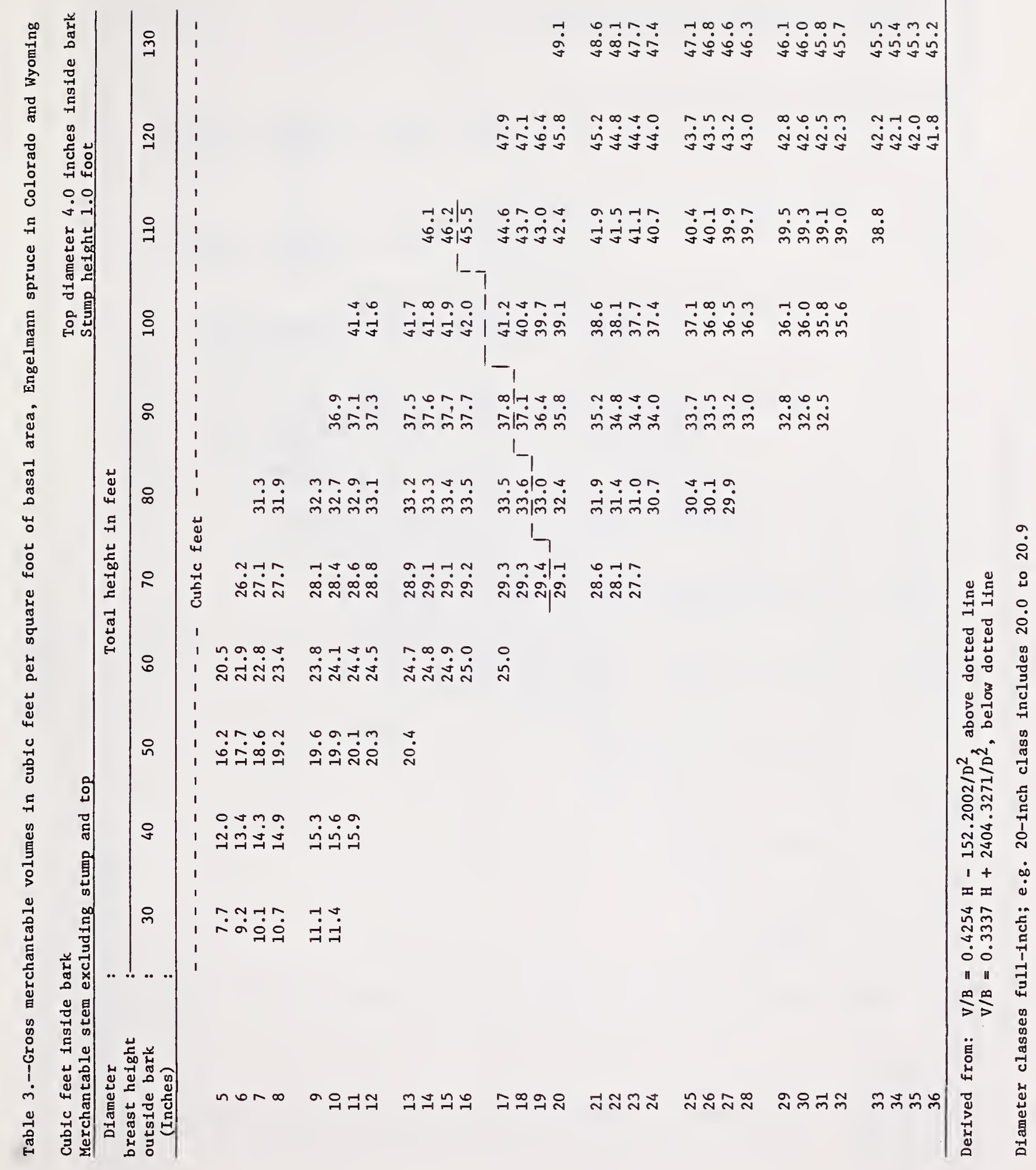




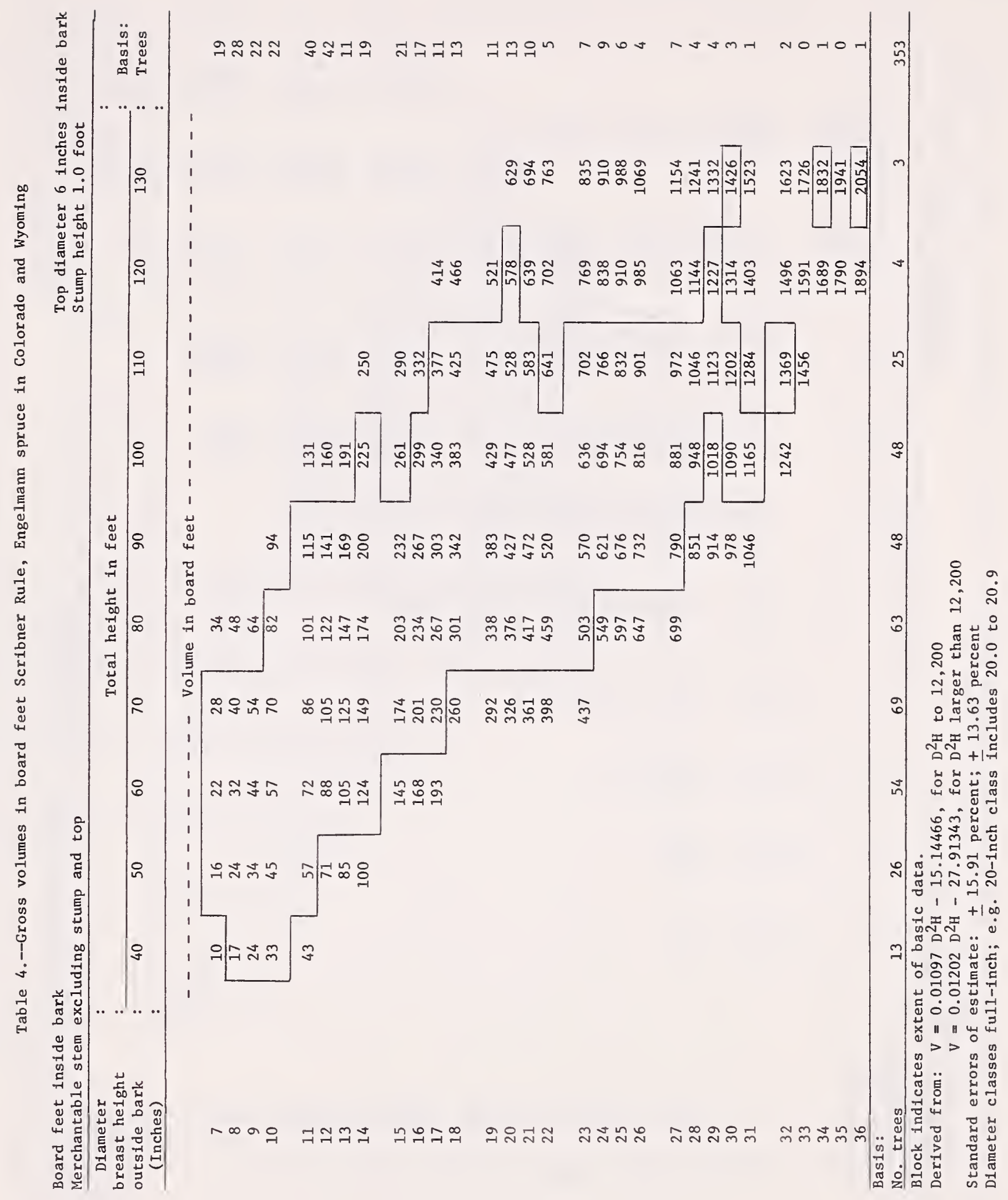




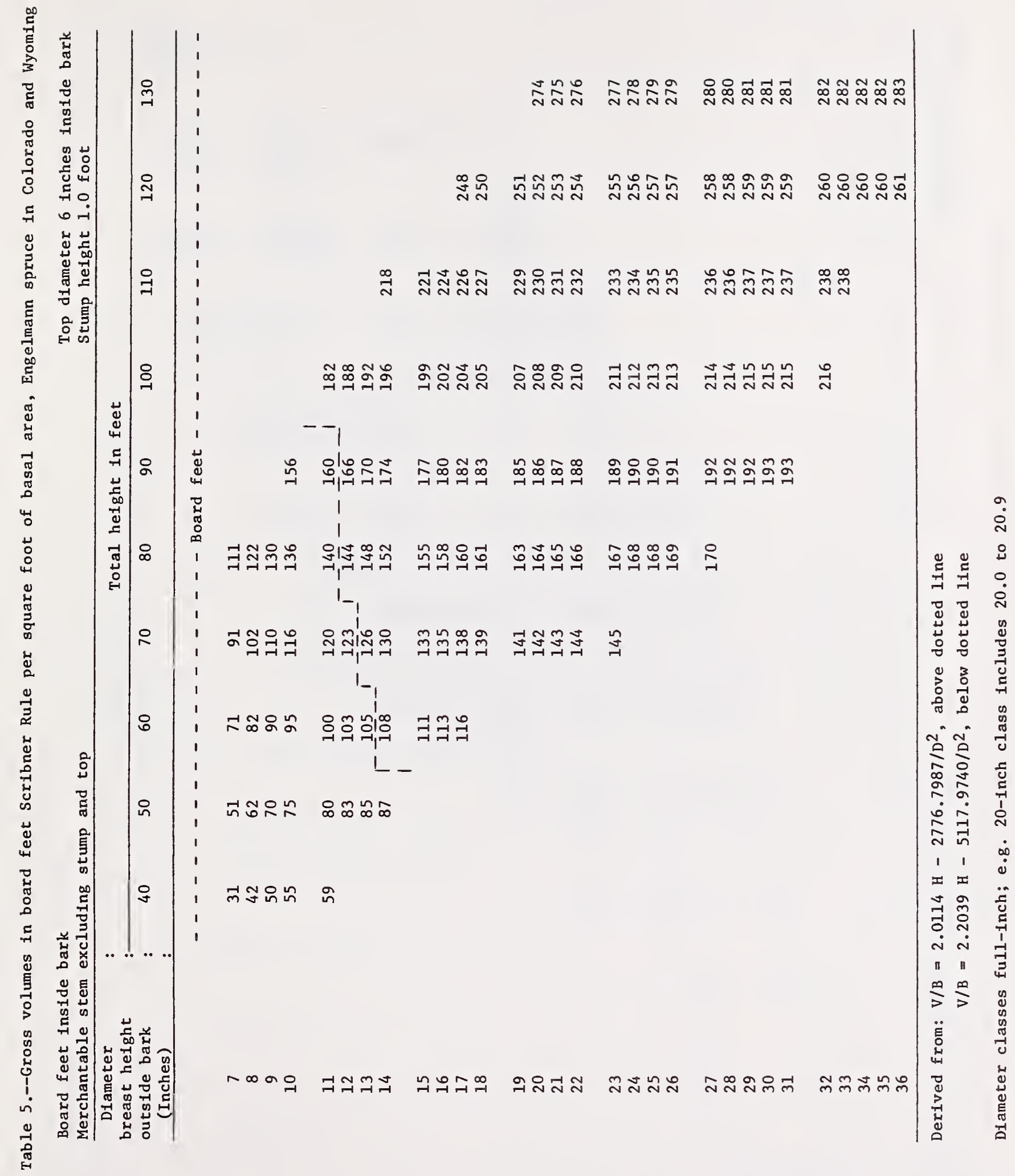




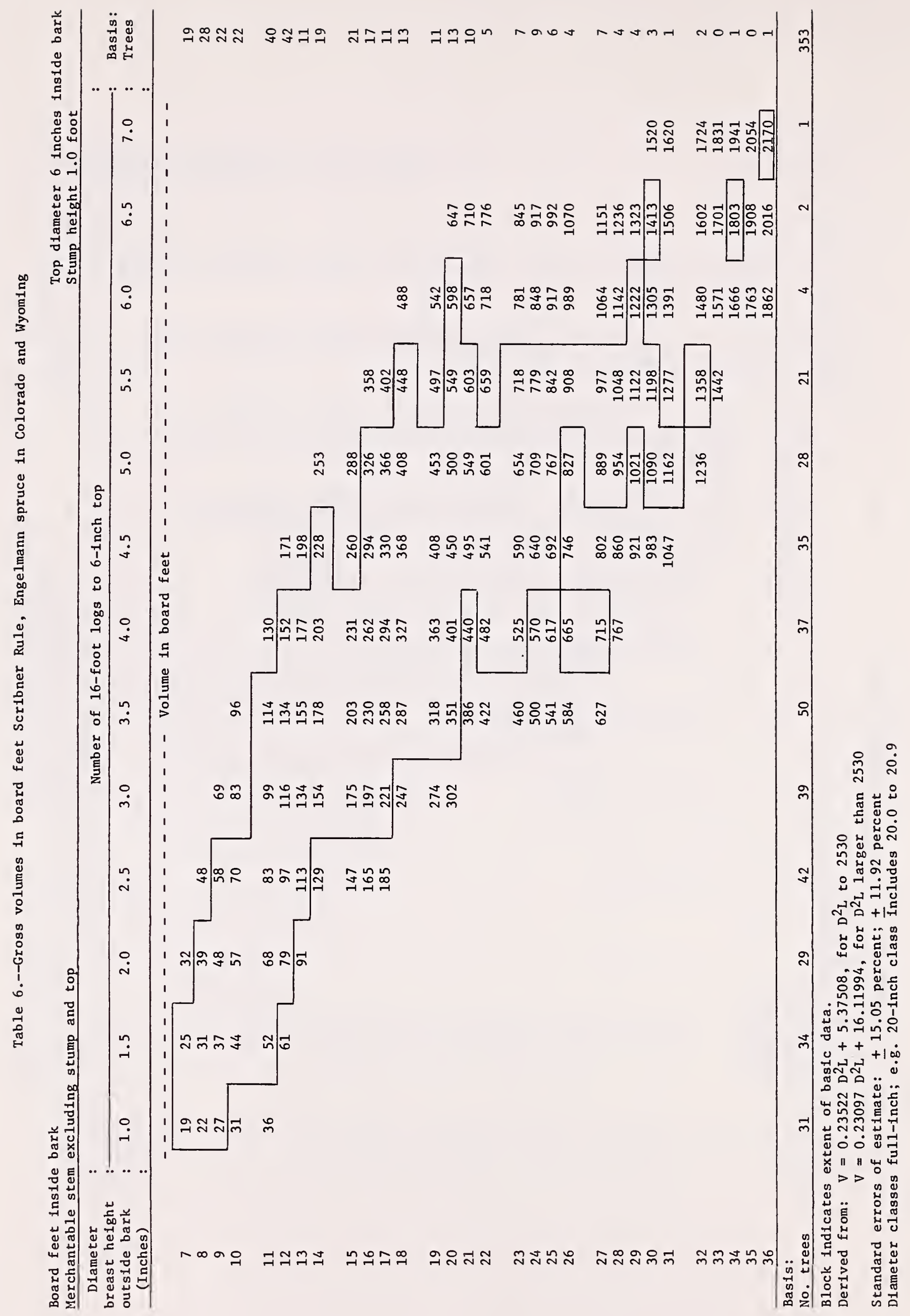




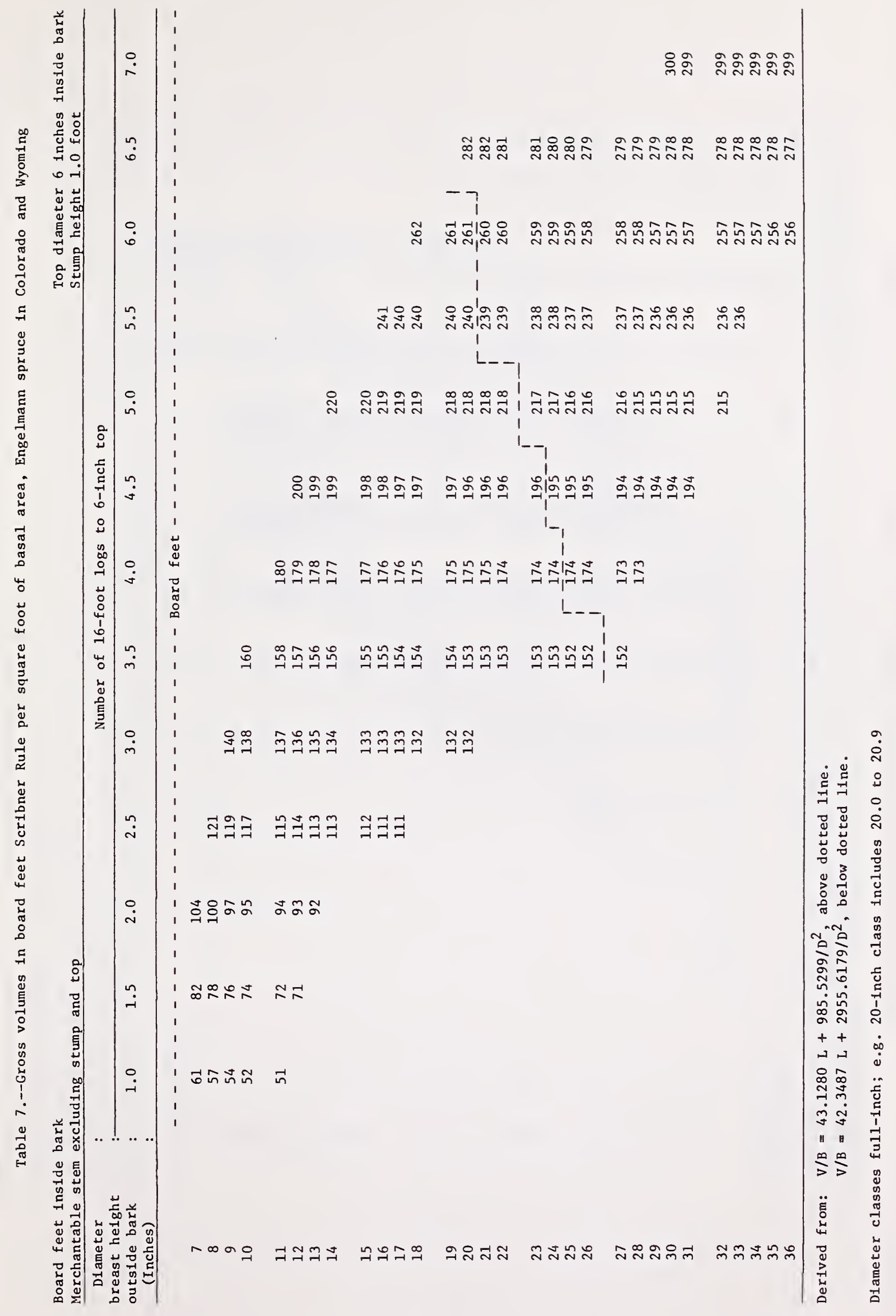




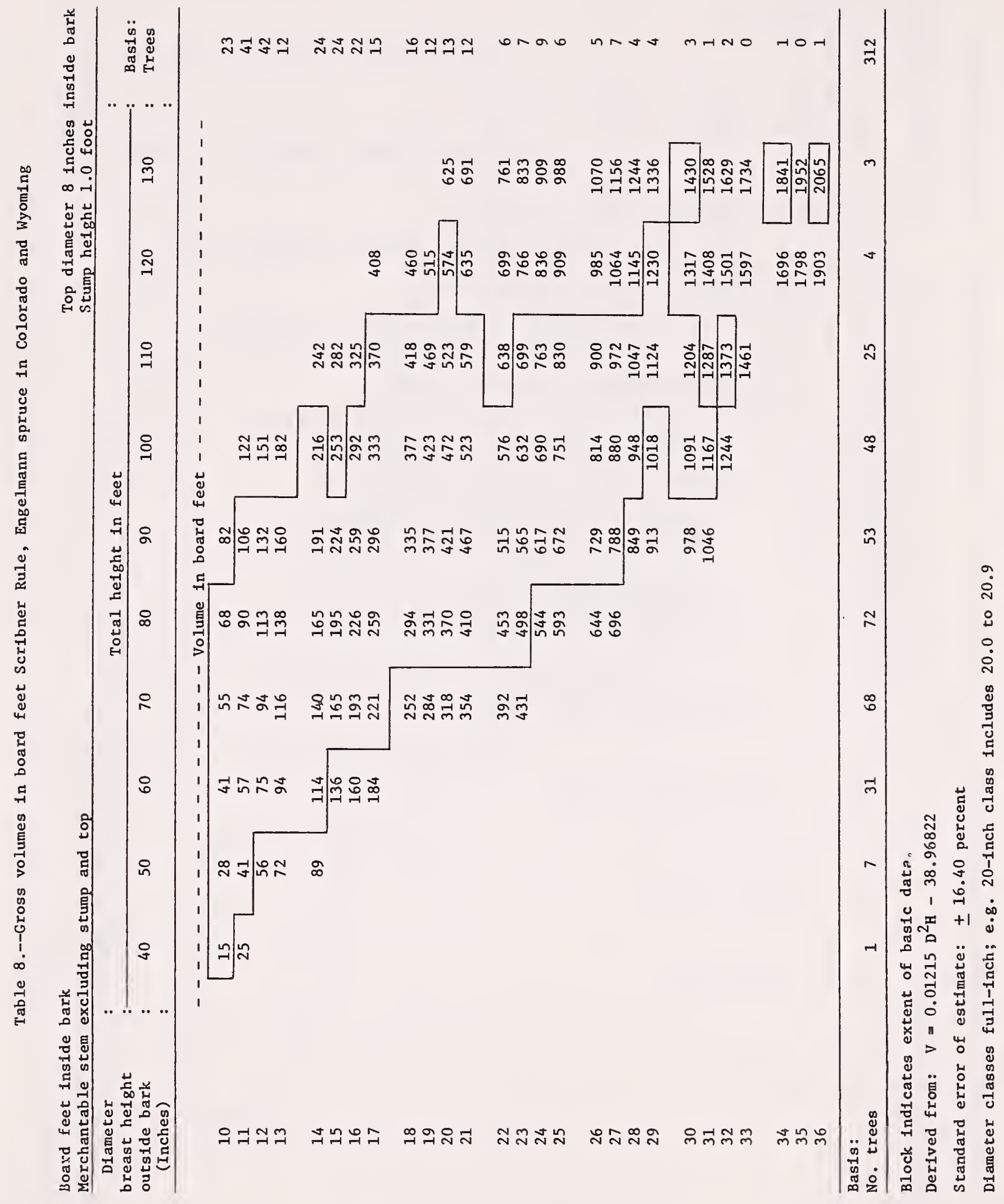




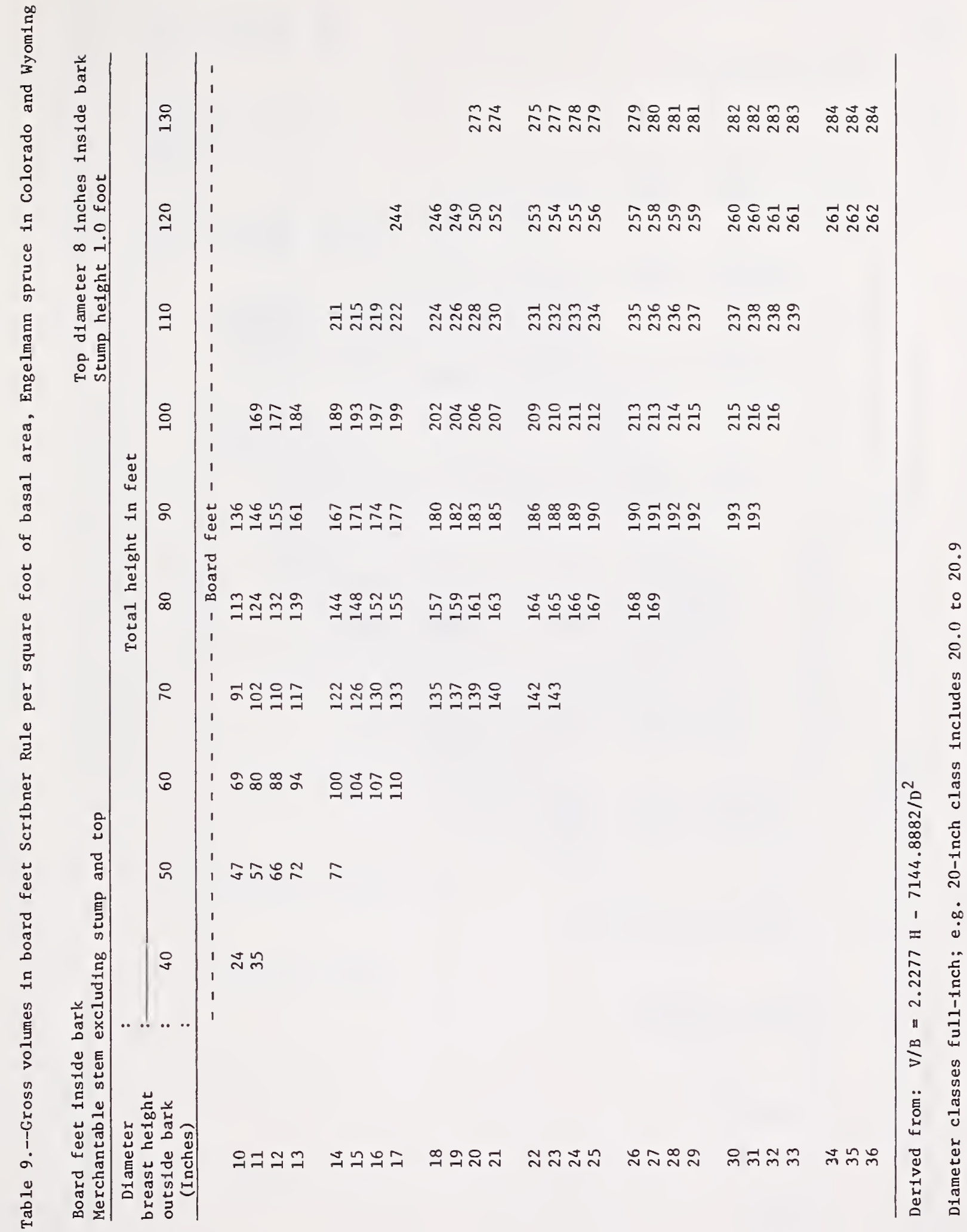




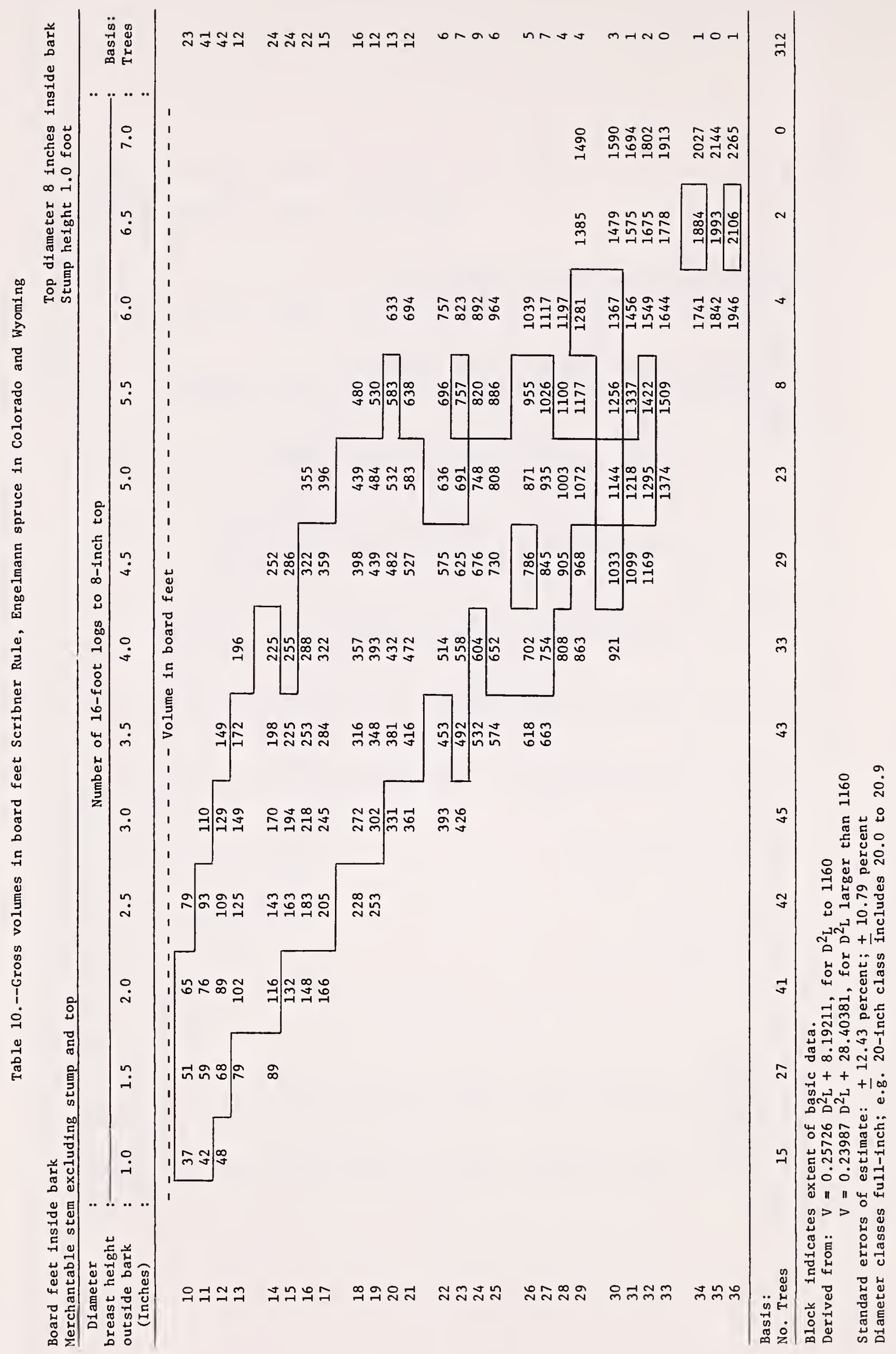




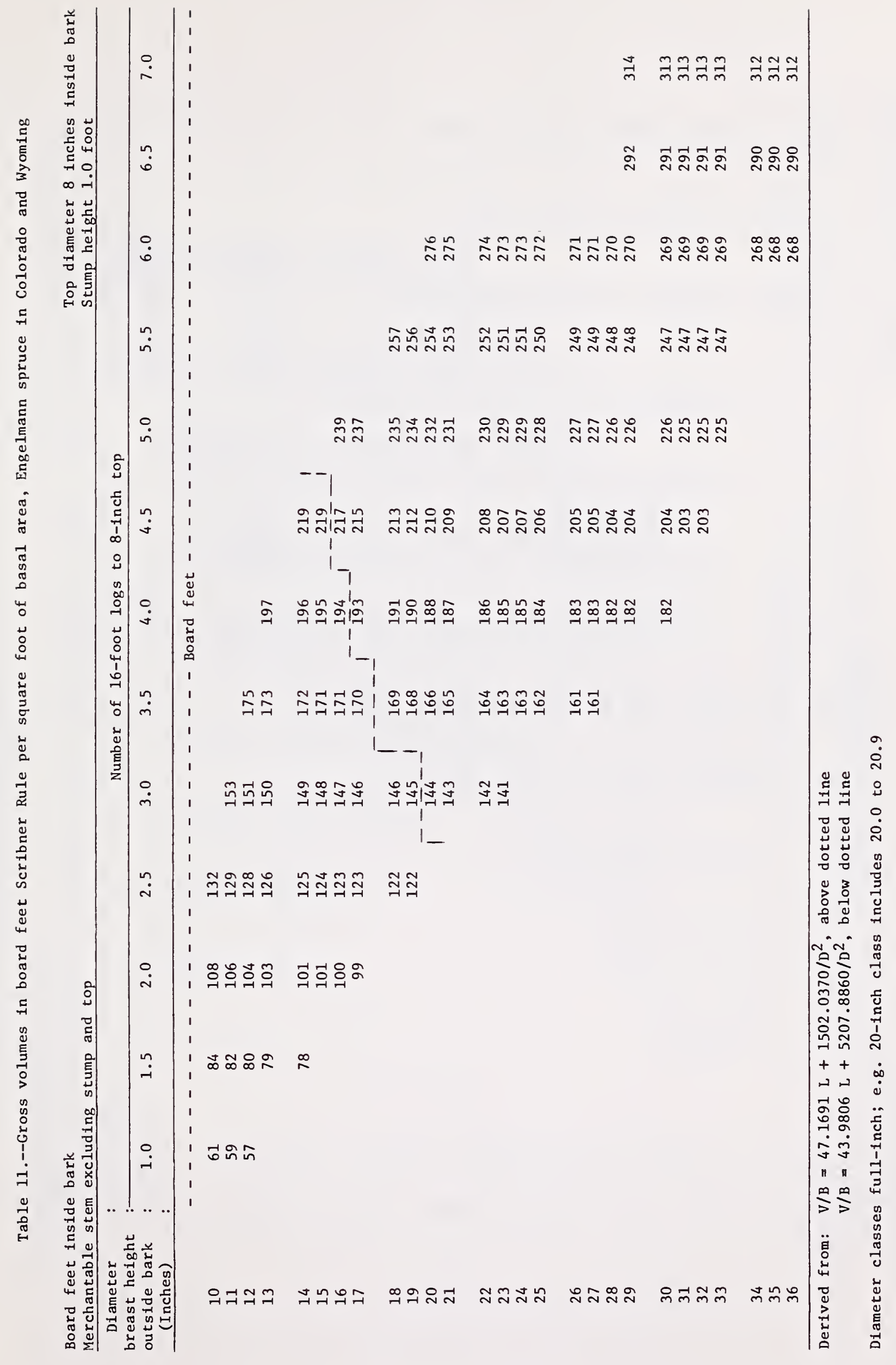




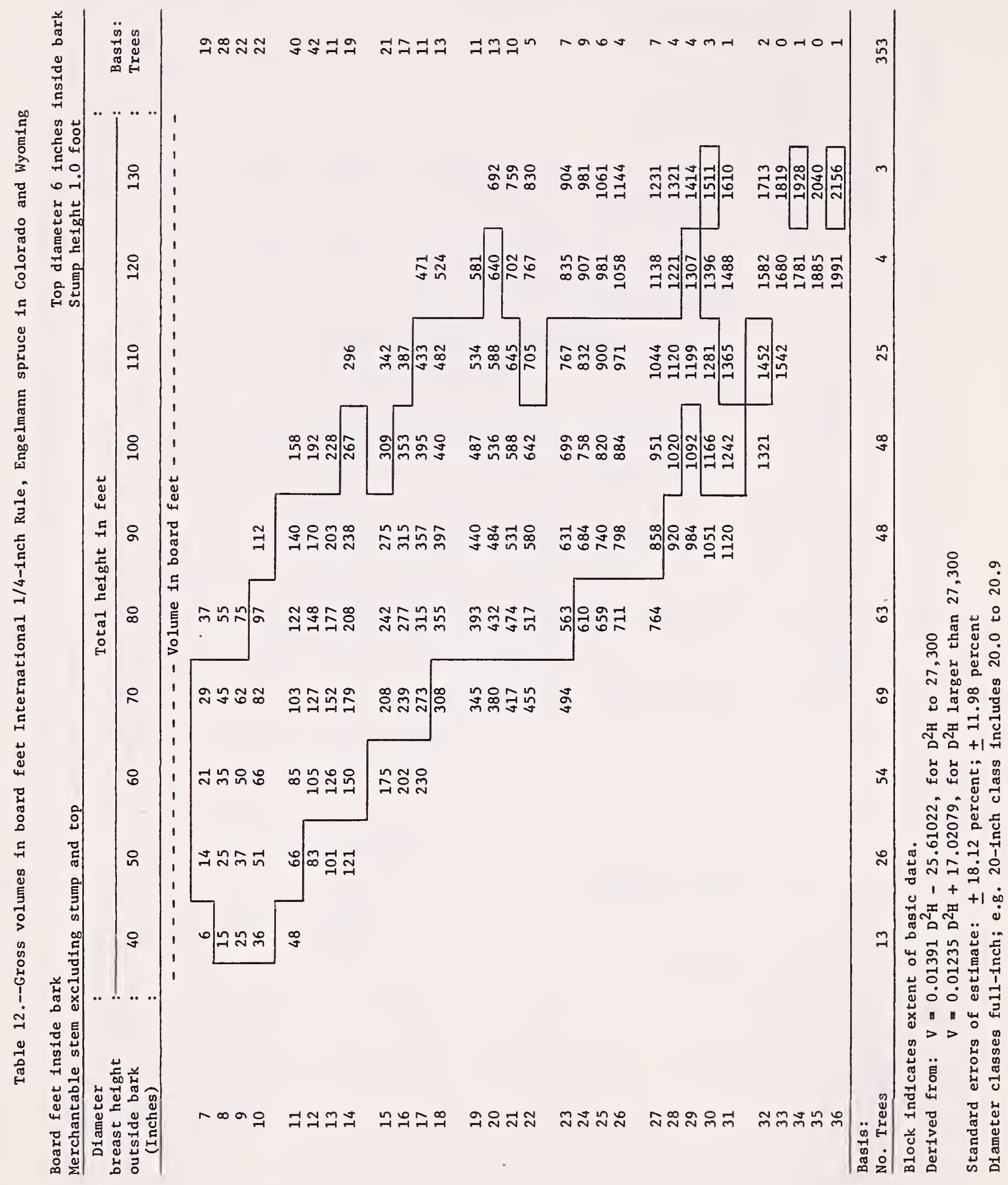




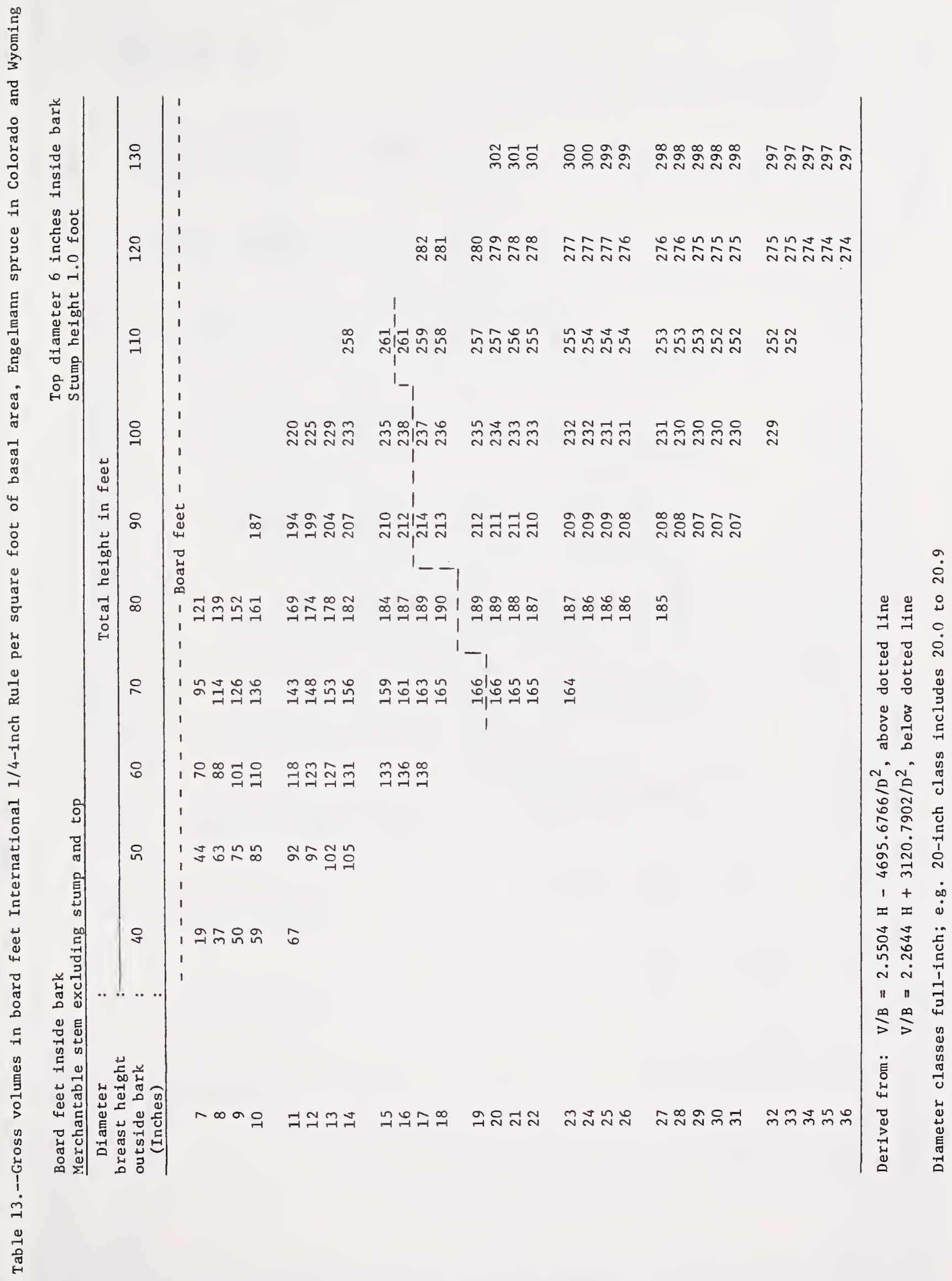




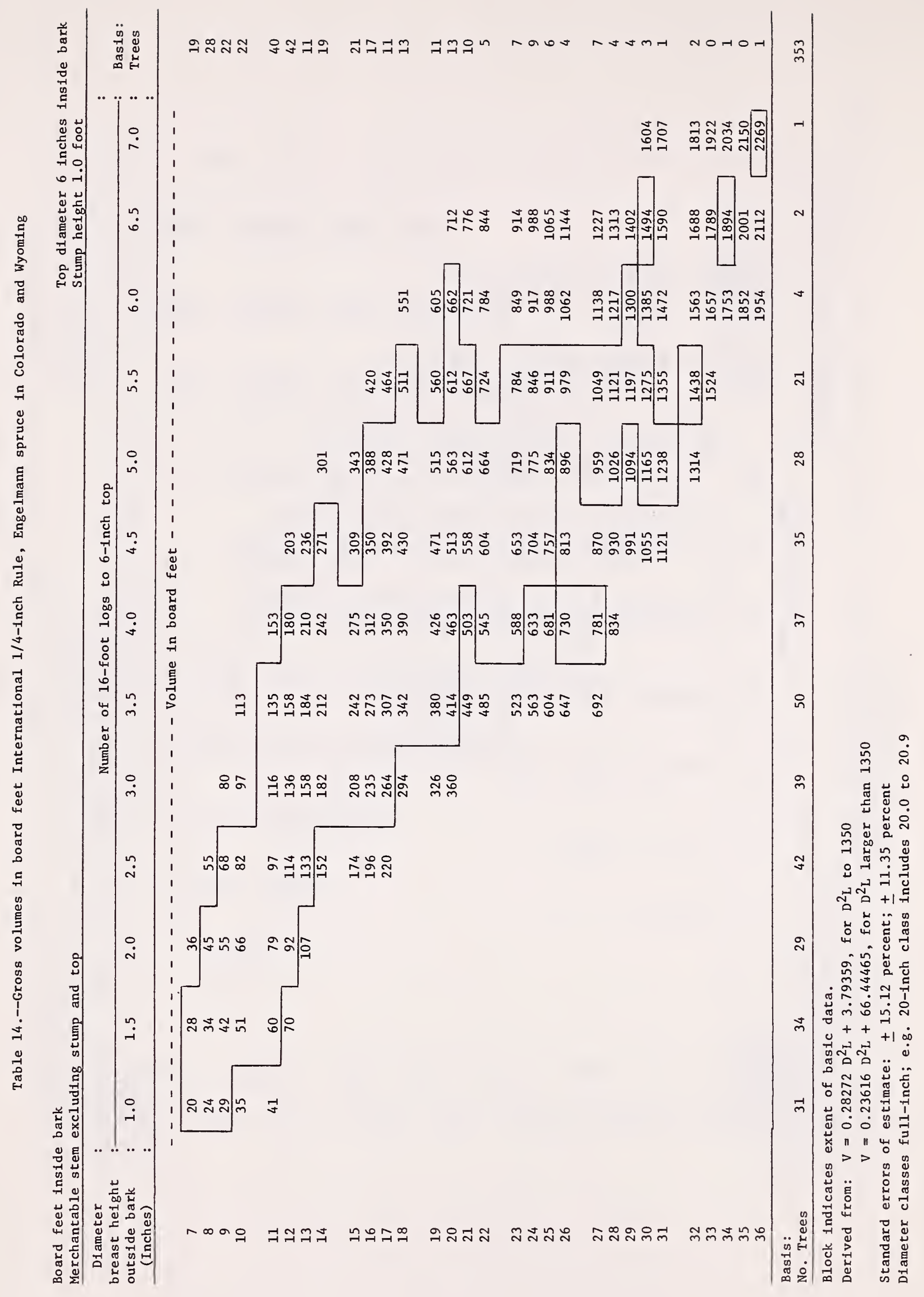




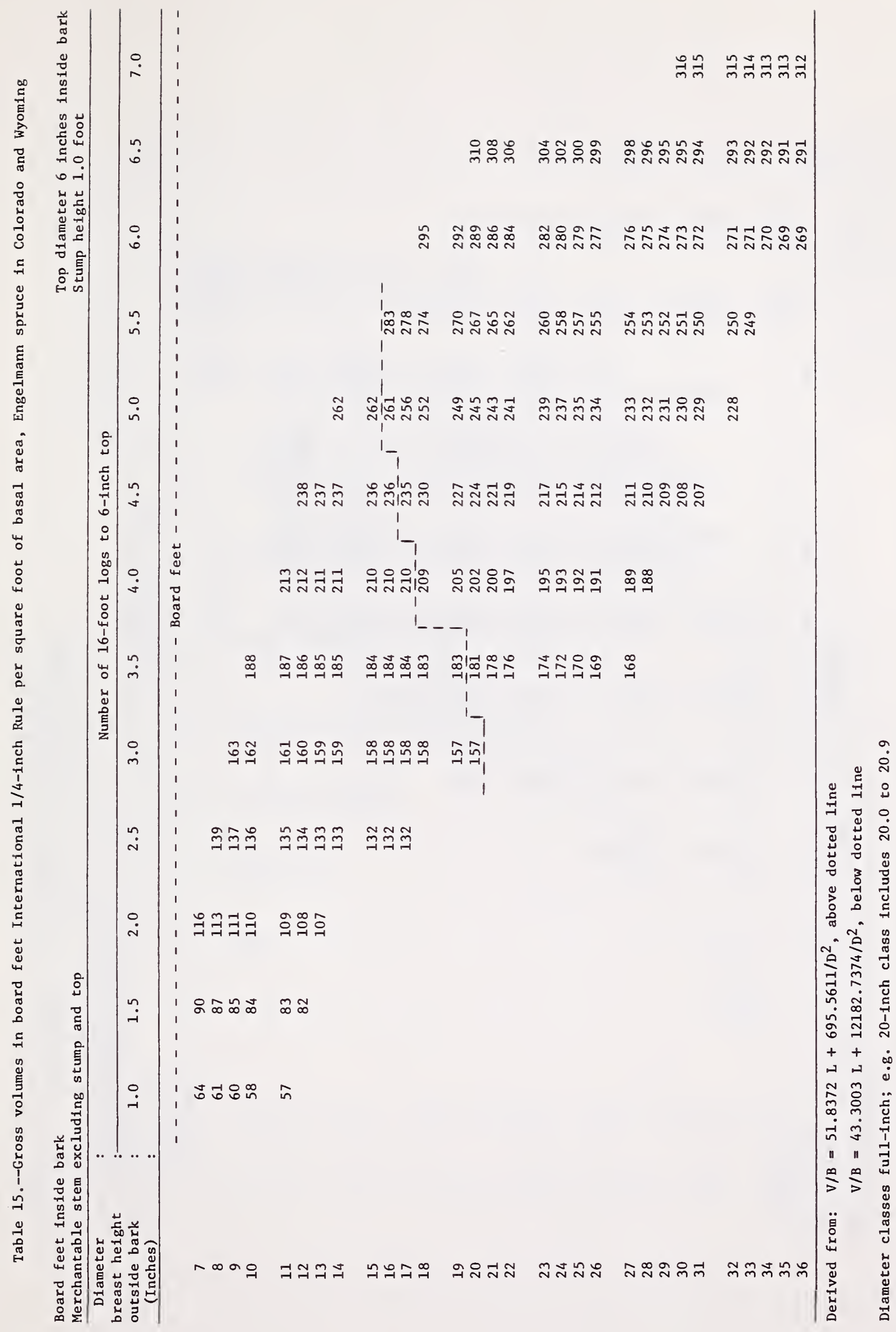




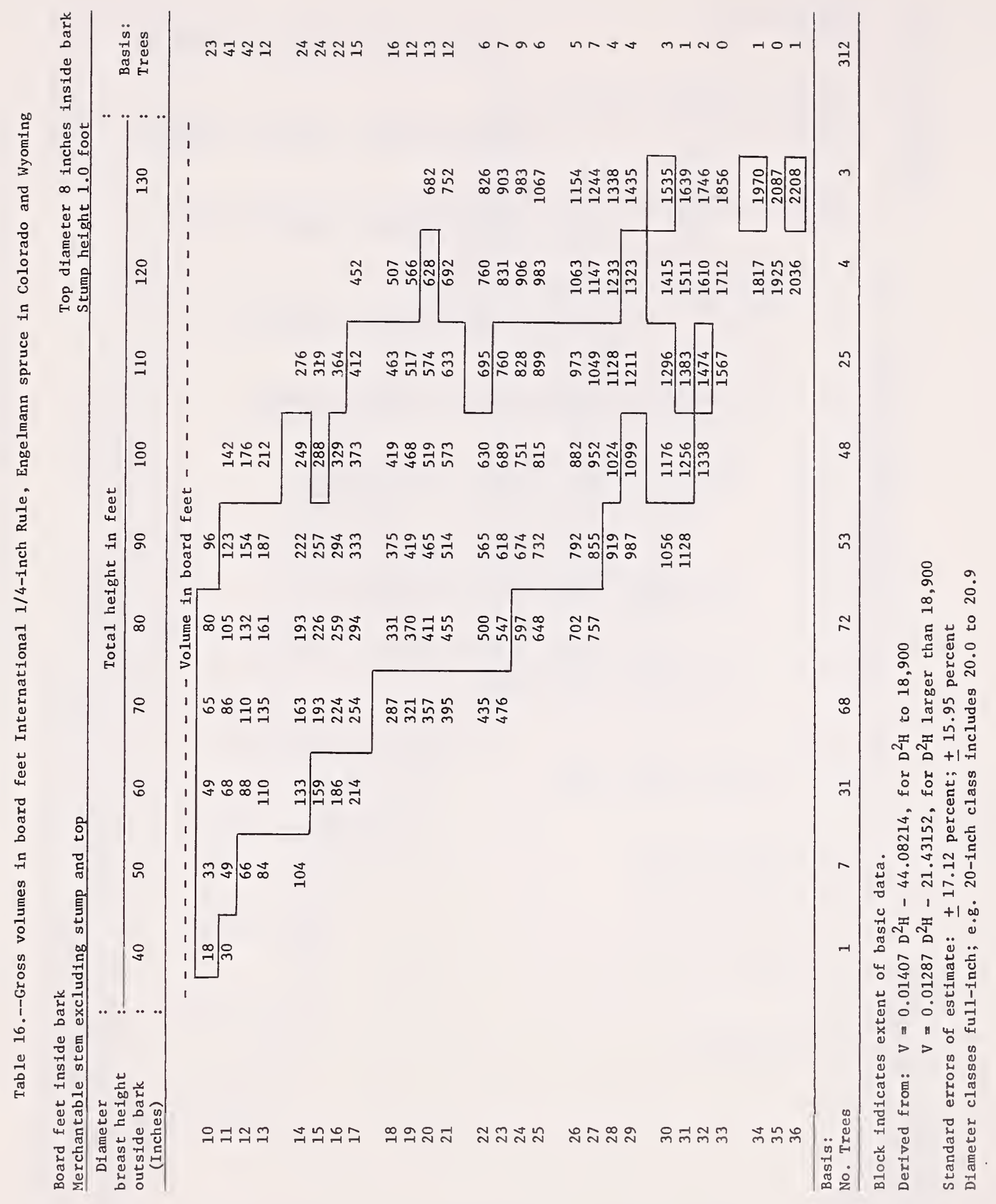




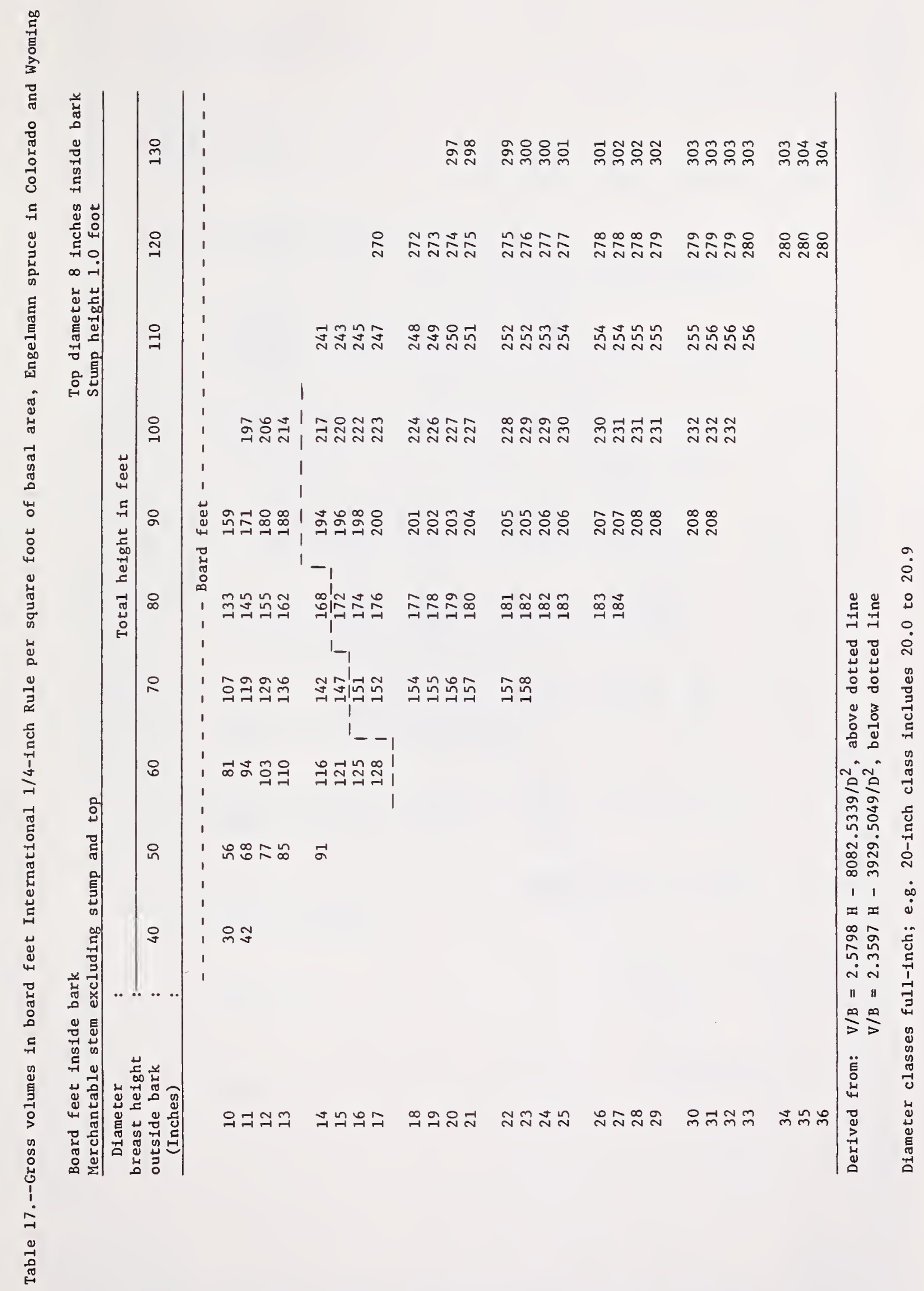




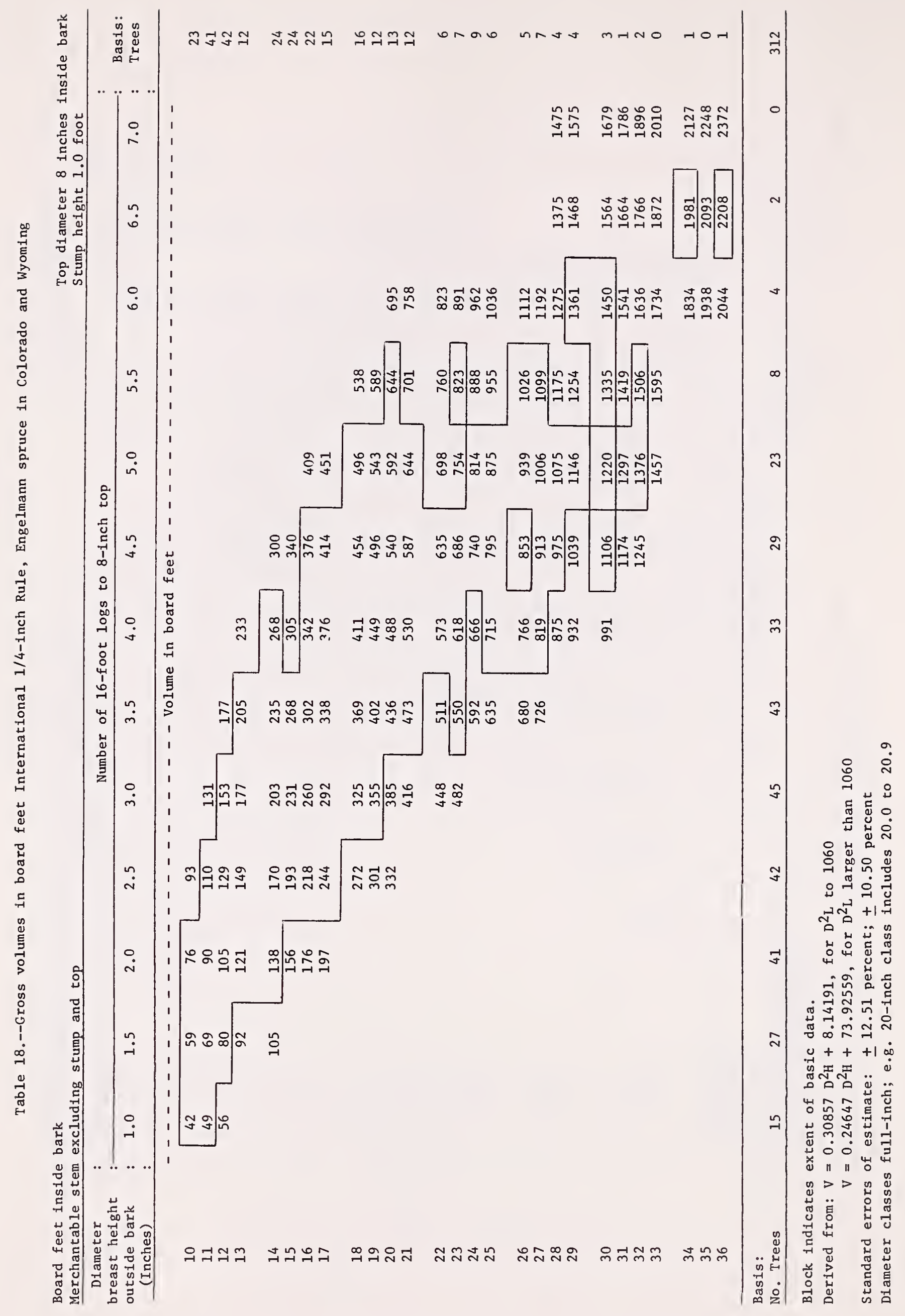




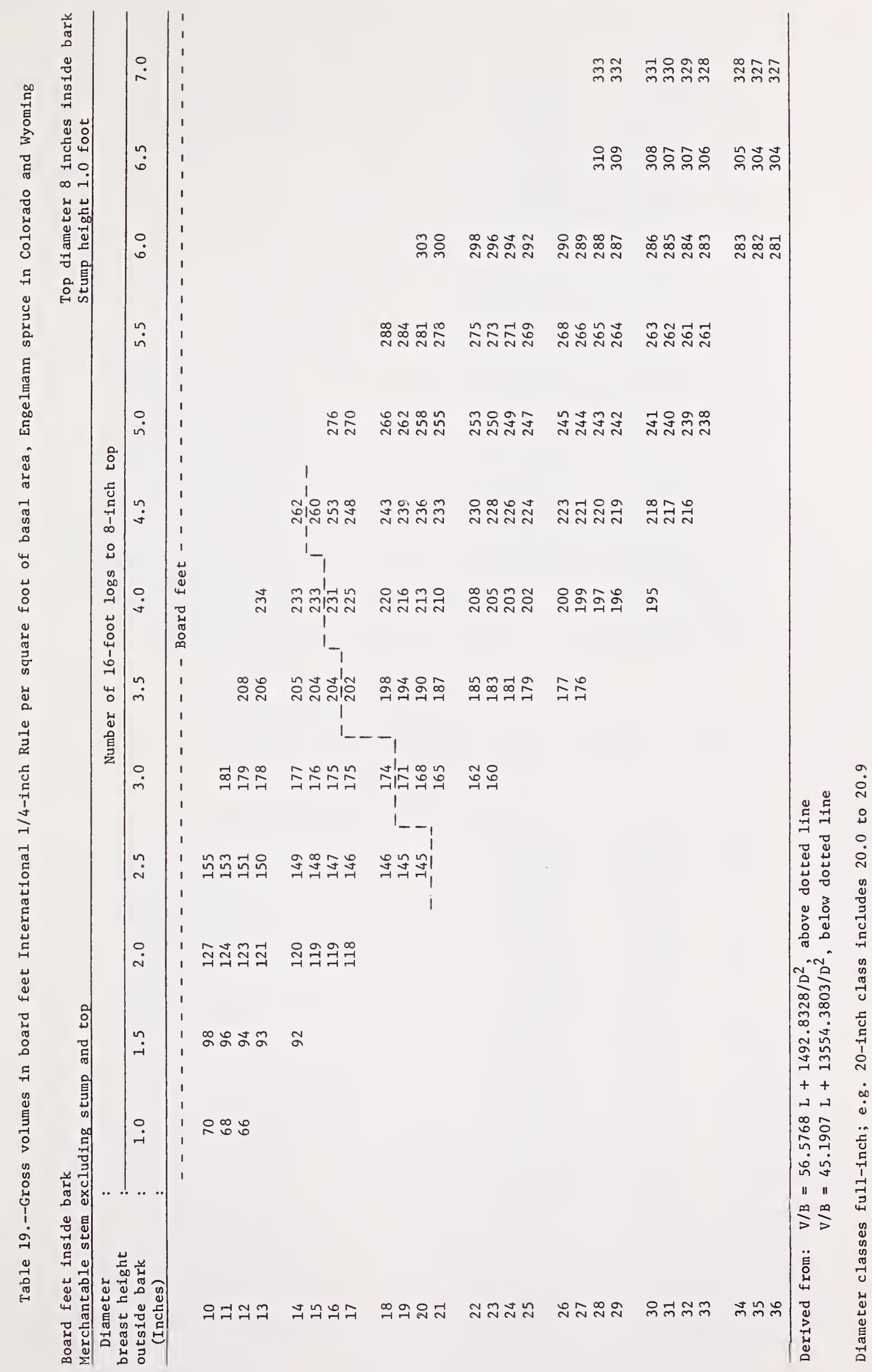




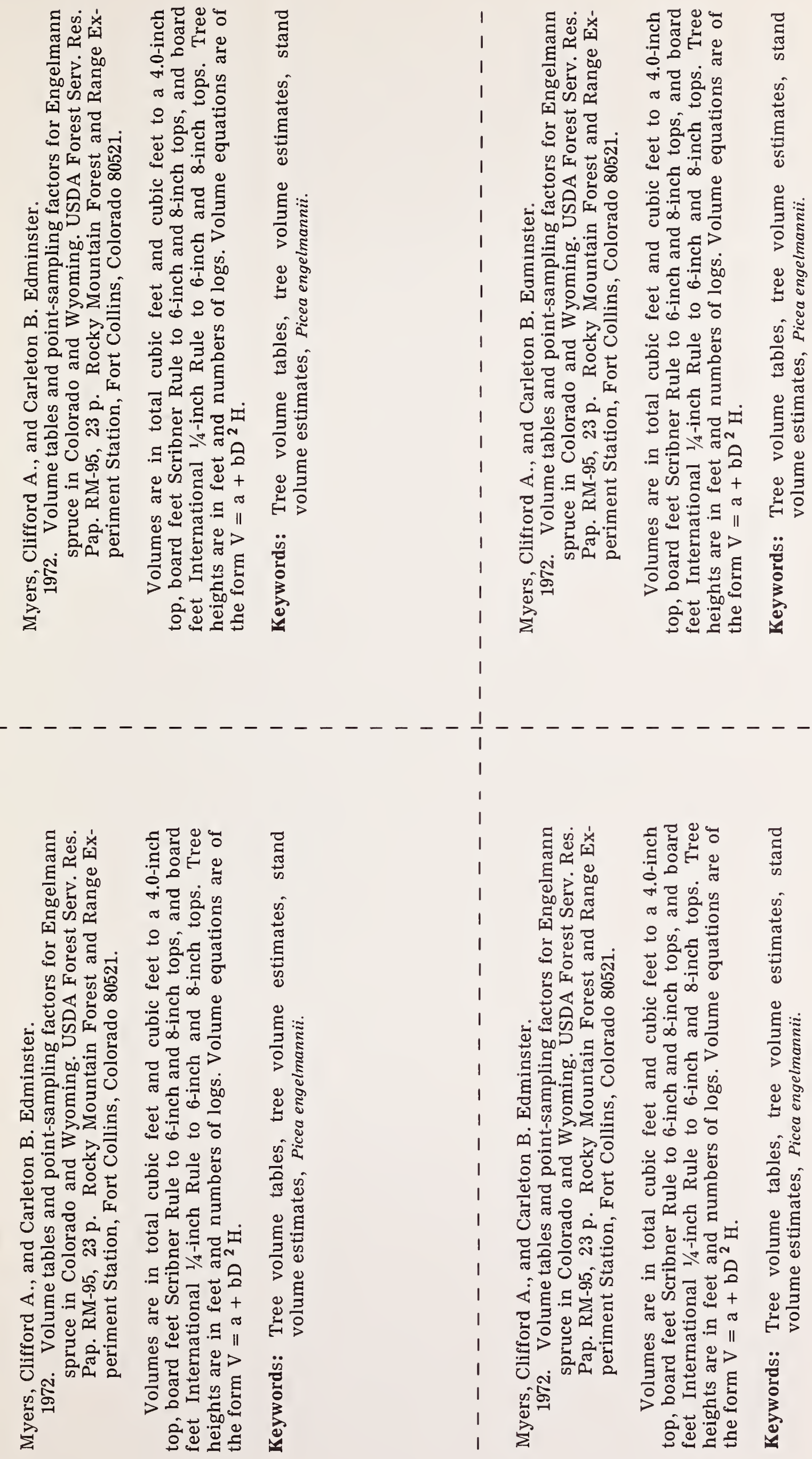


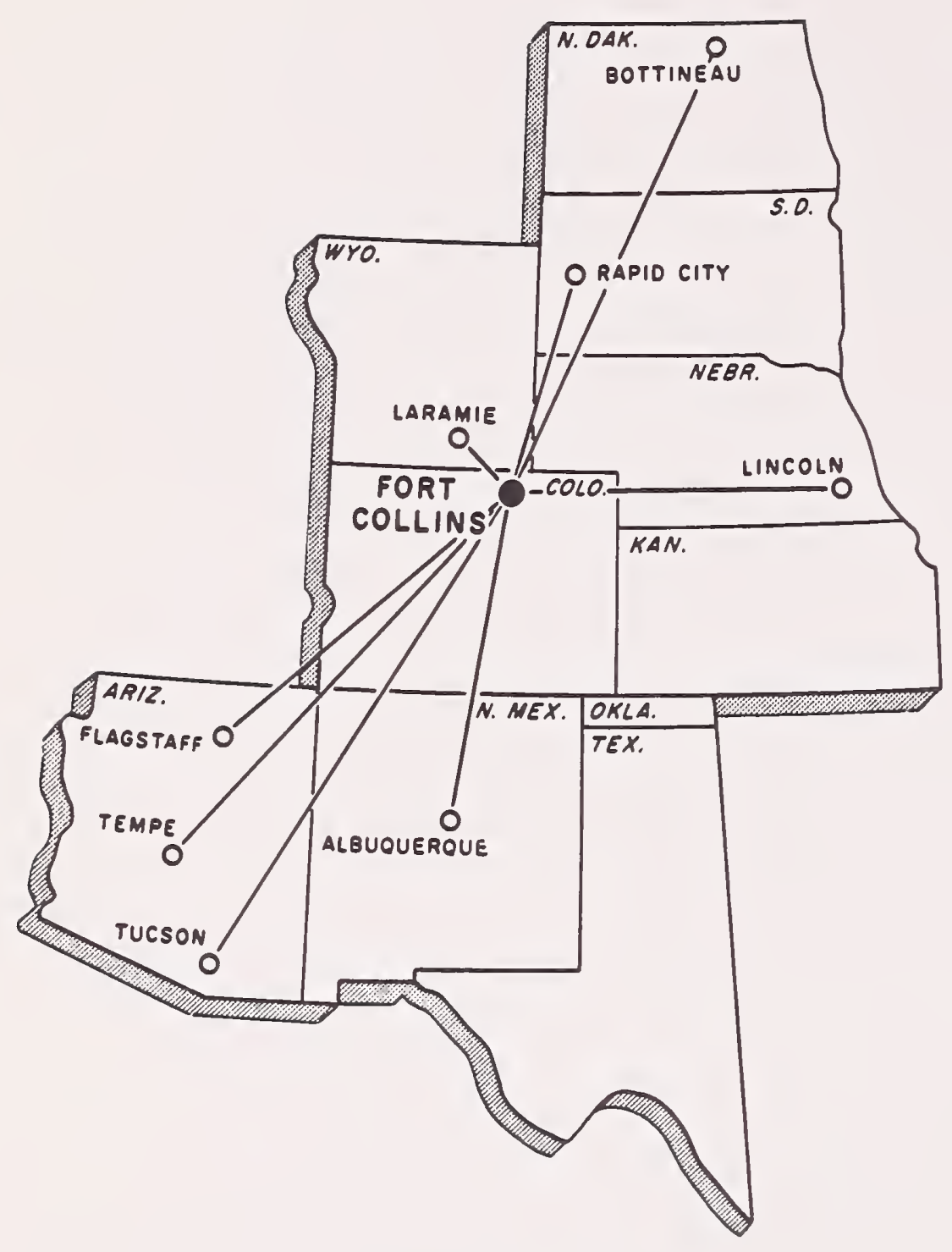

